\title{
Intracranial Self-stimulation and Stimulation Produced Analgesia of the Nucleus Submedius in Awake Rats
}

\author{
Kentaro Murase ${ }^{1}$, Eiji Sumiya ${ }^{1}$, Kaoru Okada ${ }^{1}$, \\ Kazuko Kobayashi ${ }^{2}$ and Kenji Kawakita ${ }^{1}$ \\ Department of Physiology ${ }^{1}$ and Biochemistry ${ }^{2}$, Meiji University of Oriental Medicine, \\ Kyoto, Japan
}

(Received 1 April 1997)

\begin{abstract}
Nucleus submedius $(\mathrm{Sm})$ in medial thalamus has been proposed as a thalamic relay nucleus which may mediate motivational and affective aspects of pain, and recent studies have suggested that the Sm nucleus may also participate in the pain inhibitory systems. To examine the functional role of the Sm, relationship between intracranial self-stimulation (ICSS) and stimulation produced analgesia (SPA) of the $\mathrm{Sm}$ were investigated in conscious rats $(n=15)$. The monopolar electrodes were implanted chronically, and the frequency of lever press-induced electrical stimulation $(0.3 \mathrm{~ms}, 50 \mathrm{~Hz}, 200 \mu \mathrm{A})$ was monitored and the effects of the conditioning electrical stimulation for $30 \mathrm{~s}$ on the tail flick test and formalin test were studied.

The ICSS positive sites (lever pressing over 5 times/min) were found in seven of 15 in the Sm and also distributed around the Sm. Three of seven ICSS positive sites in Sm were obviously prolonged the tail flick latency immediately after electrical stimulation. In formalin test, most of these ICSS positive sites decreased the licking duration during the stimulation and the effects continued after stimuli in four ICSS positive sites. On the other hand, ICSS neutral sites (lever pressing less than 5 times $/ \mathrm{min}$ ) had some analgesic effects on both tests but they were not so apparent.

These results suggest that the Sm nucleus is not a simple thalamic relay of nociceptive information to the cortex, and it also participates, at least in part, in pain inhibitory systems with rewarding property.
\end{abstract}

Key words : nucleus submedius, intracranial self-stimulation, stimulation produced analgesia, endogenous pain inhibitory systems, rat

視床内側下核における脳内自己刺激と刺激誘発鎮痛

村瀬健太郎 ${ }^{1}$ 角谷 英治 $^{1}$ 岡田 $\quad$ 櫓 $^{1} \quad$ 小林 $^{\text {和子 }}{ }^{2} \quad$ 川喜田健司 $^{1}$

1明治鋮负大学 生理学

2明治銊尒大学 生化学 


\section{緒言}

視床内側核群の 1 つである内側下核 (nucleus submedius: Sm) は, 数多くの神経解剖学的研究から, 痛覚情報の中継核の 1 つとされたおり ${ }^{4}$ ，ニューロ

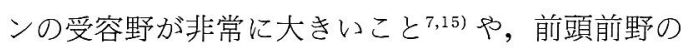
脳底側にある腹外側眼窩皮質 (ventrolateral orbital cortex：VLO) と相互投射していること神) などから， 痛みの弁別的な相よりもむしろ情動相に関係すると 考えられてきた。近年, Sm 核の破壊で痛覚過敏が生 じる ${ }^{13)}$ ，また Sm 核の通電刺激で tail flick 潜時の延 長 ${ }^{18)}$ や, 脊䯣後角ニューロンの抑制 ${ }^{19}$, 直腸結腸の 伸展刺激で誘発される外腹斜筋の筋電活動の抑制 ${ }^{16)}$ などの報告があり，内因性鎮痛系に $\mathrm{Sm}$ 核が積極的 に関与している可能性が示唆されている.

中枢神経系の特定部位の情動面での役割を知るた めの方法として，脳内自己刺激（intracranial selfstimulation: ICSS)が挙げられる年. ICSS はそれが positive とされる部位では情動としての快情報と関 連していると考えられており，Sm核におけるICSS の検討は，その機能を知るうえで有用な情報を提供 すると考えられる.しかし，視床のICSS に関する研 究はきわめて少なく, Sm 核の ICSS を調べた報告で はneutral とされている3)が, その例数はわずか 1 例 のみであり結論的なものとはいえない.

そこで, 本研究では Sm 核の機能的役割を知るた めに, Sm 核における ICSS の有無について調べた。 次に tail flick test と formalin test を指標に，通電刺 激による内因性鎮痛機構に対する役割を調べ, ICSS と刺激誘発鎮痛 (stimulation produced analgesia: SPA）との関連について検討した。

\section{方 法}

\section{1. 電極埋め込み手術}

実験にはWistar系雄性ラット（手術時体重 290〜380 g）15匹を用いた。手術はネンブタール (50 mg/kg, i.p.) 麻酔後, 定位脳固定装置 (成茂, ST-7）に固定し，直腸温をモニターして，体温を 約 $37.5^{\circ} \mathrm{C}$ に保った。実体顕微鏡下で頭蓋骨を露出 し，刺激電極刺入部位（bregmaより尾側 $2.1 〜$ $2.5 \mathrm{~mm}$, 外側 $0.6 \sim 0.8 \mathrm{~mm}$ ) にデンタルドリルを用 いて孔 $(\phi 0.8 \mathrm{~mm})$ を開けた。刺激電極として金属微 小電極 (東洋医療研究所製, 直径 $180 \mu \mathrm{m}$, インピー ダンス $10 \mathrm{M} \Omega$ )を用い, 油圧式マニピュレーター(成 茂，PF5-1）により，Paxinos\&Watsonのラット脳 地図 ${ }^{12)}$ 参考に目的の深さまで刺入した。アース用 ビス（直径 $1 \mathrm{~mm}$, 高さ $2 \mathrm{~mm}$ ）を頭蓋骨に固定後, 電極とソケットを接続し, デンタルセメントで固定 した。麻醉が覚めた後, 飼育用ケージに戻し, 1 週間 の回復期問をおいて実験を開始した。

\section{2. 脳内自己刺激}

オペラント行動観察にはアルミ製のレバーを取り 付けたスキナーケージ（東洋産業株式会社, MSK003）を用いた。手術回復期間の後, 餌報酬学習でレ バー押し訓練を開始し, 規定数（毎分 2 回）以上に なったところで，餌報酬を脳内通電刺激に変え，10 分間の ICSS のレバー押し回数を調ベ, ペンレコー ダーに記録した.脳内通電刺激は基準電流を $200 \mu \mathrm{A}$ とし,ラットがレバーを押すことをトリガーとして， 定電流刺激装置 (日本光電，SEN-3201）からアイソ レータを介して刺激が流れるようにした（interval $20 \mathrm{~ms}$, duration $0.3 \mathrm{~ms}$, train 50, 1 秒間).このと き実際に流れた刺激強度は, $100 \mathrm{~K} \Omega$ の抵抗を介し てオシロスコープ (KIKUSUI, COS5060-ST) でモ ニターした.

\section{3. tail flick test}

tail flick test には, 輻射熱式鎮痛効果測定装置 (米 国 IITC 社, model 33)を用い, ラットの尾部末端に 輻射熱を照射し，ラットが尾を振り動かすまでの潜 時を記録した。ベースライン潜時が 3.5〜 4.5 秒にな るように熱源の強さを調節し, ラットの尾の組織損 傷を防ぐために，反応に関係なく 10 秒間で自動的に 切れるようにした. 2 分間隔で 5 回の試行の後, 脳内 通電刺激 $(0.3 \mathrm{~ms}, 50 \mathrm{~Hz}, 200 \mu \mathrm{A})$ を 30 秒間行い, 刺激終了直後から同じく 2 分間隔で 5 回の試行を行 った。評価は刺激前 5 回試行の平均を $100 \%$ として 変化率を算出し，20\% 以上潜時が延長したものを鎮 痛効果が認められたものとした。 


\section{4. formalin test}

formalin test は, $2.5 \%$ ホルマリン液 $50 \mu l$ を $26 \mathrm{G}$ 針を用いてラットの右後肢足底部に皮下注射 した後, 床下に角度 45 度で鏡をとりつけたプラスチ ックゲージに入れ，疼痛関連行動を観察した。疼痛 関連行動の指標として, 注射された足を舐める(licking) 時間を計測した. Dubbissonらの方法に従い ${ }^{6)}$, ホルマリン注入後，30 分経過した第二相の licking 行動が安定したところで脳内通電刺激 (0.3 ms, $50 \mathrm{~Hz}, 200 \mu \mathrm{A})$ を 30 秒間行った。観察は刺激前 (pre)，刺激中 (stim)，刺激後 (after) のそれぞれ 30 秒ごとの licking をしている時間をペンレコーダー に記録した。

\section{5. 刺激部位の組織学的検討}

実験終了後，直流通電（20 $\mu \mathrm{A} ， 10$ 秒) でマーキ ングを行い，灌流固定，染色は定法に従って行い， ラットの脳地図 ${ }^{12)}$ を用い組織学的に脳内刺激部位 を同定した。

\section{結＼cjkstart果}

\section{1. 脸内自己刺激}

ICSS は，レバー押しによる慨報酬 (feeding) 期間 から脳内通電刺激または無刺激の条件に切り替え， 10 分間のレバー押し回数を計測し，1 分間あたりの 回数で比較した. feeding 期間や脸内通電刺激がない 条件下でのレバー押し回数は,それぞれ $2.9 \pm 0.1$ 回/ $\min , 2.8 \pm 0.4$ 回 $/ \min (\operatorname{mean} \pm \mathrm{SE})$ であった（Fig

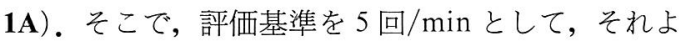
りも多いものを ICSS positiveとし， 5 回 $/ \mathrm{min}$ 以下 は ICSS neutral とした。その典型例を Fig. 1B, C に 示す.

最初の 1〜2 回はレバー押しを行うものの, その後 ICSS を全く行わないICSS negative の例は Sm 核内 で 1 例，Sm核周辺に扔いては視床下部背側野で 1 例みられたのみであった。そこで今回は特に区別せ ず両者とも neutral として分類した。

\section{2. 脳内自己刺激と刺激誘発鎮痛の関連}

Sm 核内 15 例のうちで ICSS positive の例は 7 例 認められ, ICSS neutral の例は 8 例であった（Fig.

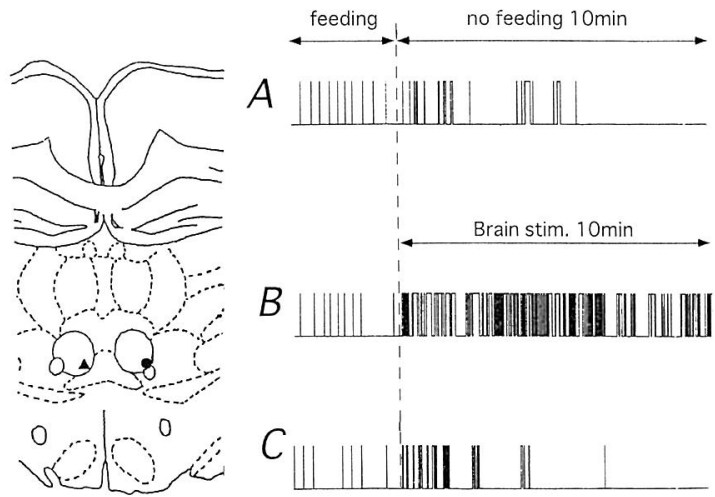

Fig. 1 Examples of lever press recording of ICSS. When the rat pressed the lever, a pellet was given during feeding session, then intracranial stimulations were applied. A : no electrical stimulation to the brain; $\mathbf{B}$ : electrical stimulation applied to the sites of closed circle in the brain map (ICSS positive); $\mathbf{C}$ : closed triangle (ICSS neutral). $\mathrm{Sm}$ : submedius nucleus

2A). SPAの効果について比較してみると, ICSS positive の部位に関しては, tail flick 潜時の顕著な延 長が 7 例中 2 例，延長が 1 例みられ，他の 4 例では 変化は認められなかった。 formalin test では stim 中 に licking 期間が減少した例は 7 例中 6 例みられ,そ のうち 5 例では afterにおいても刺激効果が持続し た(Fig. 2B，C上のグラフ)。一方， ICSS neutralの 部位に関しては, tail flick 潜時の延長は 8 例中 1 例 認められ，他の7 例では変化はなかった。 formalin test では stim 中に licking 期間が減少した例は 8 例 中 5 例みられたが, その効果は持続せず after におい ては pre に戻る傾向が観察された（Fig. 2B，C下の グラフ). Sm 核内においては, ICSS positive の部位 が, tail flick test と formalin test において脳内通電 刺激が効果的である傾向が認められた。

Sm 核周囲では，ICSS positiveは 7 例，ICSS neutral は 8 例で散在して認められたが, 視床下部背 側野の 5 例では，ICSS positive は 1 例も認められな かった (Fig. 3A). これらの部位での SPA の効果に ついて比較してみると, ICSS positive の部位に関し ては, tail flick 潜時の延長が 7 例中 2 例みられ，他 の 5 例では変化は認められなかった. formalin test 

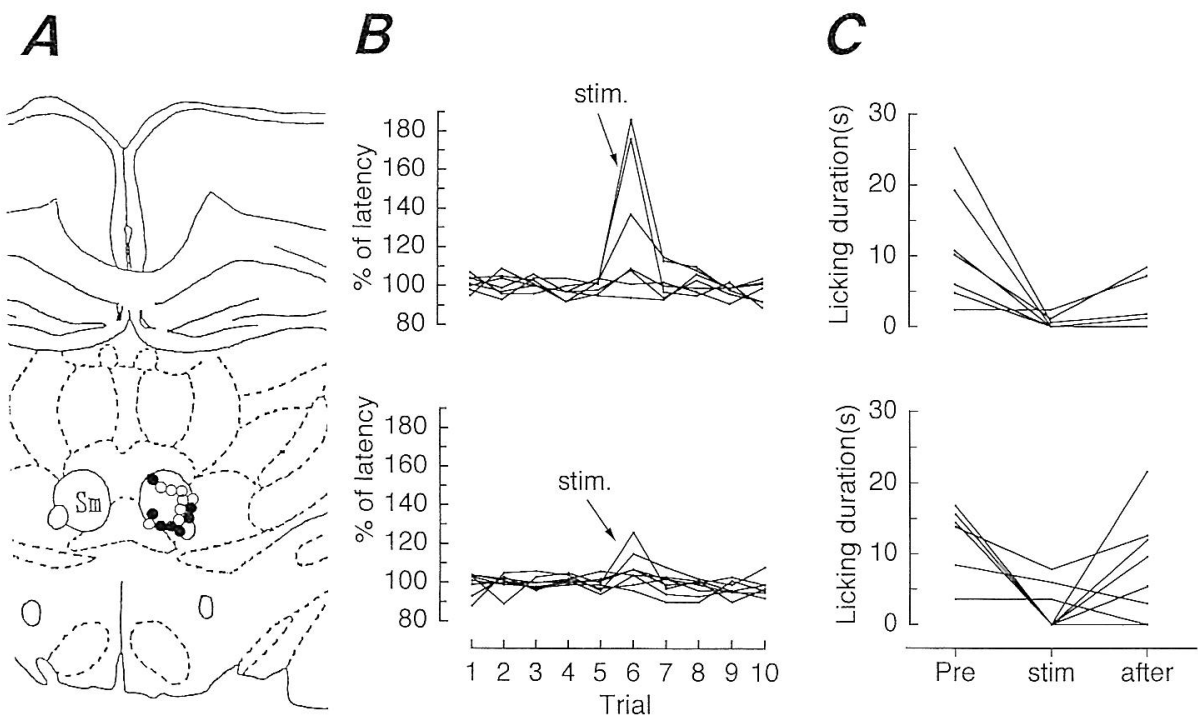

Fig. 2 Relationship between ICSS and SPA in the Sm. A : closed circles in the brain map indicate the sites of ICSS positive and open circles indicate the ICSS neutral. B : effects of electrical stimulation on the tail flick test. Upper figure shows the results of ICSS positive sites $(n=7)$ and lower figure shows that of ICSS neutral sites $(n=8)$. C : effects of electrical stimulation on the licking duration in the formalin test. See text for more detailed explanation.
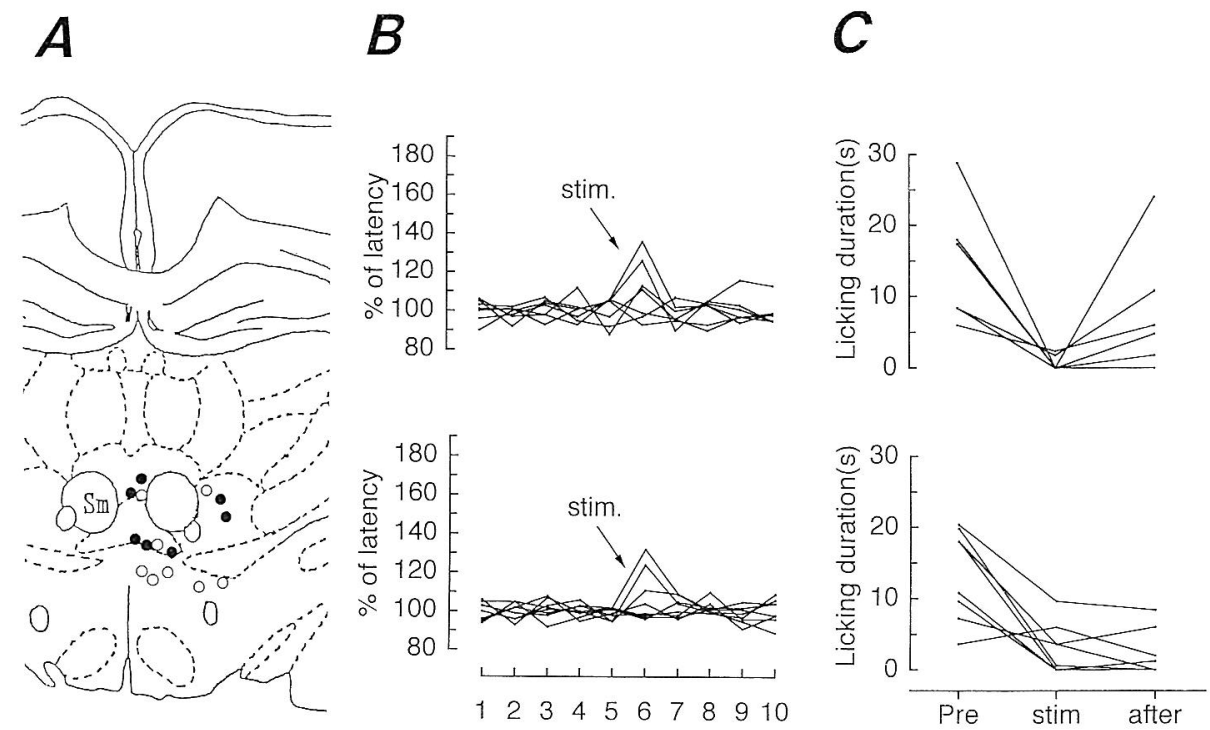

Fig. 3 Relationship between ICSS and SPA in the sites around the Sm. Details are the same in the Figure 2.

では stim 中は全例で licking 期間が減少し，そのう ち 4 例では afterにおいても抑制効果が持続した。一 方, ICSS neutral の部位に関しては, tail flick 潜時 の延長は 8 例中 2 例認められ，他の 6 例では変化は なかった. formalin test では stim 中に licking 期間が
減少した例は 8 例中 6 例みられ，この 6 例はすべて after も効果を持続した (Fig. 3B，C)。これら Sm 核 周囲では, tail flick test と ICSS との関連は認められ なかった. formalin test ではstim 中は ICSS positive の方が抑制する例が多いが，afterではむしろ ICSS 
neutral の部位で効果が持続する例が多く, ICSS と SPA との関連は認められなかった。

\section{考察}

\section{1. 脳内自己刺激}

Olds らは，間脳とその隣接領域における報酬系お よび罰系の経路に関する詳細な検討を行い，報酬系 は視床下部の外側に位置する内側前敛束の走行と一 致することを明らかにし，視床内側核群では報酬系 と嫌悪系が混在していると報告している ${ }^{11}$. その後, Clavier らは視床内に限局して ICSS の実験を行い, 視床の腹内側核 (VM) や䯣板内核群で positiveな ICSS を認めたが, Sm 核での ICSS は 1 例で, neutral と分類していた ${ }^{3)}$.今回の実験の結果では Sm 核を含 む視床内側核群において ICSS positive と neutral は 混在していたが, Sm 核では約半数 (7/15) の部位で ICSS が認められ, ICSS negative は1例のみであっ た.このことは, Sm 核と痛みの情動面との密接な関 連性を示唆する神経解剖学的な知見からは予想外の 結果であるが, 内因性鎮痛系との関連からは與味深 いものである。また，これらの部位の中には，定型 行動を伴いながらレバー押し行動をする例がみられ た。自らレバーを押した後レバーから遠ざかる行動 は，この部位の脳内通電刺激が単純な報酬的意味だ けでないことを示唆しており，より複雑な反応が生 じていると考觉られた。

\section{2. 刺激誘発鎮痛}

tail flick test の結果では, Sm 核の 2 例で著明な潜 時の延長が認められたが，全体としては顕著ではな かった.Zhang らは, 麻酔下のラットの Sm 核腹側部 の通電刺激により, tail flick 潜時の延長したことを 報告している18)。しかし，Roberts らは，Sm核を破 壊した覚醒下のラットで，脊髄よりも上位の中枢が 関与しているとされる vocalization を誘発させる通 電刺激閾值は下るが, tail flick の潜時は変化がなか ったと報告している ${ }^{13)}$. 両報告の結果が異なった理 由としては，刺激実験と破壊実験という実験方法の 違いや，麻酔下と覚醒下という実験条件の違いなど が考えられる, formalin test の結果では, 脸内通電刺
激期間中はいずれの刺激部位でも licking 行動が抑 制される傾向にあり，部位や効果に差は認められな かった。 その理由として, 通電刺激が licking 行動に 直接影響を与えた可能性や, 通電刺激強度を $200 \mu \mathrm{A}$ で 30 秒間の一定条件下で行ったことなどが考えら れる。しかし，脳内通電刺激後も抑制効果が持続し た部位においては，その刺激が鎮痛をもたらしたも のと考えられた.Sm核通電刺激の影響を formalin test を用いて調べた報告は本研究が最初であり，今 回の結果は $\mathrm{Sm}$ 核と痛覚の情動面の関連から大変興 味深いものである.

今回，SPA の指標として tail flick test と formalin test を用いた結果，後者で鎮痛を示す例が多く観察 された. 従来 SPA の研究で用いられてきた tail flick test のような瓷髄反射 ${ }^{2}$ と，より高次の中枢が関与 するとされている formalin testでは，鎮痛機序が異 なることが指摘されており ${ }^{1)}, \mathrm{Sm}$ 核がより高次の中 枢に対して作用することを示唆している.

\section{3. 視床内側下核における脳内自己刺激と刺激誘}

\section{発鎮痛の関連}

今回の実験で, Sm 核内の ICSS positive の部位と, neutral の部位では, 刺激直後の tail flick 潜時と formalin test の after で通電刺激の効果に違いがみ られ，ICSS positive の方が，より鎮痛効果が顕著な 例が多かった。このことから，Sm核における SPA とICSSには何らかの関連のあることが示唆され た。一方，Sm 核周囲では明らかな関連は認められな かった. ICSS positive 領域と SPA 領域の関係につ いて, Mayer らは, ICSS とSPA は関連がなかった としている ${ }^{8)}$.しかし，Dennisらは，PAG 腹側部に おいてICSS と formalin test を用いたSPAに対し ては強い関連があると報告している5)。また，黒質 (substantia nigra) や青斑核 (locus coeruleus) にお いてもICSS と SPA の部位が一致する部位もある という報告もみられ ${ }^{14)}$ ，見解は一致していない。一 方，痛みの中継核として弁別相に関与するとされる 視床腹側基底核群は，ICSS においても neutral であ $り^{8)}$ ，また，SPAを生じないという報告がある97. Sumiya らも, 直腸結腸の伸展刺激で誘発される外腹 
斜筋の筋電活動に Sm 核の通電刺激では抑制が認め

られるが，腹側基底核群では抑制は認められなかつ たとしている16).これらの結果は, 痛覚の中継核が必 ずしも鎮痛系や報酬系と関連していないことを示す ものである。

今回の実験により Sm核において ICSS と SPA が一致する部位が認められ, Sm 核における痛覚情 報処理過程において鎮痛系および報酬系と関連した 修飾が行われている可能性が示唆された。

\section{文 献}

1) Abbott, F. V. and Melzack, R., Dissociation of the mechanisms of stimulation-produced analgesia in tests of tonic and phasic pain, In : J. J. Bonica (Eds.), Advances in Pain Research and Therapy, Vol. 5, Raves Press, New York, 1983, pp. 401-409.

2) Bonnycastle, D. D., Cook, L. and Ipsen, J., The action of some analgesic drugs in intact and chronic spinal rats, Acta Pharmacol. Toxicol., 9 (1953) 332-336.

3) Clavier, R. M. and Gerfen, C. R., Intracranial self-stimulation in the thalamus of the rat, Brain Res. Bull., 8 (1982) 353-358.

4) Craig, A. D. and Burton, H., Spinal and medullary lamina I projection to nucleus submedius in medial thalamus: a possible pain center, $\mathbf{J}$. Neurophysiol., 45 (1981) 443-466.

5) Dennis, S. G., Choiniere, M. and Melzack, R., Stimulation-produced analgesia in rats : assessment by two pain tests and correlation with self-stimulation, Exp. Neurol., 68 (1980) 295-309.

6) Dubuisson, D. and Dennis, S. G., The formalin test : a quantitative study of the analgesic effects of morphine, meperidine, and brain stem stimulation in rats and cats, Pain, 4 (1977) 161-174.

7) Kawakita, K., Dostrovsky, J. O., Tang, J. S., and Chiang, C. Y., Responses of neurons in the rat thalamic nucleus submedius to cutaneous, muscle, and visceral nociceptive stimuli, Pain, 55 (1993) 327-338.

8) Mayer, D. J. and Liebeskind, J. C., Pain reduction by focal electrical stimulation of the brain : an anatomical and behavioral analysis, Brain Res., 68 (1974) 73-93.

9) Morgan, M. J. and Franklin, K. B. J., Stimulation-produced analgesia (SPA) from brain- stem and diencephalic sites in the rat: relationships between analgesia, aversion, seizures and catalepsy, Pain, 33 (1988) 109-121.

10) Olds, J. and Milner, P., Positive reinforcement produced by electrical stimulation of septal area and other regions of rat brain, J. Comp. Physiol. Psycol., 47 (1954) 419-427.

11) Olds, M. E. and Olds, J., Approach-avoidance analysis of rat diencephalon, J. Comp. Neurol., 120 (1963) 259-295.

12) Paxinos, G. and Watson, C., The rat brain in stereotaxic coordinates, 2nd edition, Academic Press, Inc., San Diego, 1986.

13) Roberts, V. J. and Dong, W. K., The effect of thalamic nucleus submedius lesions on nociceptive responding in rats, Pain, 57 (1994) 341-349.

14) Sandberg, D. E. and Segal, M., Pharmacological analysis of analgesia and self-stimulation elicited by electrical stimulation of catecholamine nuclei in the rat brain. Brain Res., 152 (1978) 529-542.

15) Sumiya, E., Response characteristics of the rat thalamic submedius nucleus and effects of the conditioning stimulation of the ventrolateral orbital cortex, Bull. Meiji Coll. Orient. Med., 14 (1994) 89-98.

16) Sumiya, E., Murase, K., Okada, K. and Kawakita, K., Role of the nucleus submedius in the endogenous pain inhibitory mechanisms of the rat, Pain Res., 12 (1997) 21-26.

17) Yoshida, A., Dostrovsky, J. O. and Chiang, C. $Y$, The afferent and efferent connections of the nucleus submedius in the rat, J. Comp. Neurol., 324 (1992) 115-133.

18) Zhang, Y. Q., Tang, J. S., Yuan, B. and Jia, H., Inhibitory effects of electrical stimulation of thalamic nucleus submedius area on the rat tail flick reflex, Brain Res., 696 (1995) 205-212.

19) Zhang, Y. Q., Tang, J. S. and Yuan, B., Inhibitory effects of electrical stimulation of thalamic nucleus submedius of the nociceptive responses of spinal dorsal horn neurons in the rat, Brain Res., 737 (1996) 16-24.

Address for correspondence: Kenji Kawakita, Ph.D., Department of Physiology, Meiji University of Oriental Medicine, Hiyoshi-cho, Funai-gun, Kyoto 629-03, Japan.

Tel : $+81-771-72-1181$ (ext. 275)

Fax : $+81-771-72-0326$ 